\title{
SOME BRITISH WRITINGS ON THE USE OF THE LANGUAGE LABORATORY
}

Compiled by H. H. Stern, Nov. 1968.

BUCKBY, M.

CAMMISH, N. K. "Using the language laboratory in advanced language teaching."

In Aspects of Education No. 6: A New Look at Modern Language Teaching. G. Richardson (ed)

Hull: University of Hull Institute of Education. 1967 Describes and discusses experiences in developing techniques of using language laboratory effectively with advanced learners.

DEPARTMENT OF EDUCATION AND SCIENCE

DEPARTMENT OF EDUCATION AND SCIENCE

HILTON, Margaret
Language Laboratories, Education Survey 3.

London: HMSO, 1968

Provides information about the educational use of language laboratories, and the arrangements necessary for using them to the best advantage. Gives basic principles on different types of laboratories, planning lessons, size of class, and integration of courses into the main curriculum.

Secondary School Design: Modern Languages, Building Bulletin No. 43.

London: HMSO, 1968.

Aims to show how language laboratories may be fitted into an existing school building and what the component parts of the unit should be. Illustrated with drawings and diagrams. Contains suggested layouts for large units of up to 90-100 students.

"Language Laboratory exercises for post A-level students."

Modern Languages, vol 48, no. 4 (1967) pp. 151-5. 20 forms of exercises for comprehension, accuracy and fluency.

A detailed well-informed article with many important practical suggestions. 
NEWMARK, P.

RIDDY, D.

SCULTHORP, M.A.L.
SCULTHORP, M.A.L.

VERNON, P. J. (ed).

WRIGHT, N. P.
"Some objections to the "new" language teaching." Adult Education vol. 40, no. 1, (1967) pp. $7-15$ \& 18 .

Criticism of the impoverished content of structural language teaching materials.

Encourages the inclusion of art, love, sex, religion and politics in a language textbook.

"The Way Ahead in Language learning and Teaching."

Modern Languages, vol. 49, no. 1, (March 1968), pp 1-11. A general picture of language teaching in Great Britain including the use of language laboratories.

"Language Laboratory Equipment and Modern Language Teaching."

Modern Languages, vol. 43, no. 1, March 1962, pp. 6-8. A short article indicating how the CREDIF course is used at Ealing College together with the language laboratory.

"Language Laboratory Progress." Visual Education, March 1963, pp. 6-9.

A useful summary of development.

The Use of Language Laboratories in Great Britain.

A report based on a survey by the National Committee for Audio-Visual Aids in Education. Occasional Papers no. 1. Published by National Committee for Audio-Visual Aids in Education. (first published in Visual Education, July 1965) "The sixth form in the language laboratory." Modern Languages, vol. 48, no. 2, (1967) Pp. 77-80.

Mechanical drilling no longer acceptable. A library extension with tapes of scenes from plays, talks, foreign broadcasts, anthologies of verse and prose, and voices of famous people.

Language work: dictation, passages heard on tape with questions, oral precis, simultaneous translation.

Useful articles are also found in the AVLA Journal, a quarterly published by the Audio-Visual Language Association, London, England. H. Stern. 